\title{
Recognition and treatment of sleep-disordered breathing: an important component of chronic disease management
}

Peter C. Farrell ${ }^{1 *}$ and Glenn Richards ${ }^{2}$

\begin{abstract}
Sleep-disordered breathing (SDB) is a highly prevalent condition, and is associated with many debilitating chronic diseases. The role of untreated obstructive sleep apnea (OSA) in arterial hypertension has been recognized in international guidelines. Treatment with continuous positive airway pressure (CPAP) is associated with clinically-relevant reductions in blood pressure. In heart failure (HF), SDB is associated with worse prognosis and increased mortality. Major HF guidelines recommend that patients should be treated for sleep apnea to improve their HF status. Severe OSA increases the risk of arrhythmias, including atrial fibrillation, influences risk management in stroke, and is highly prevalent in patients with type 2 diabetes. Effective treatment with CPAP improves the success of antiarrhythmic interventions, improves outcomes in stroke and reduces hyperglycemia in diabetes. Patients with coronary artery disease also have a high prevalence of SDB, which is independently associated with worse outcomes. The role of CPAP for secondary cardiovascular prevention remains to be determined. Data from large, well-conducted clinical trials have shown that noninvasive ventilation, targeted to markedly reduce hypercapnia, significantly improves survival and reduces readmission in stable hypercapnic chronic obstructive pulmonary disease. The association of SDB with chronic diseases contributes to the high healthcare costs incurred by SDB patients. SDB also has an important negative impact on quality of life, which is reversed by CPAP treatment. The high prevalence of SDB, and its association with diseases that cause significant morbidity and mortality, suggest that the diagnosis and management of SDB is an important therapeutic goal. First, adherent CPAP treatment significantly improves the quality of life of all patients with SDB; second, it eliminates the negative impact of untreated SDB on any associated chronic diseases; and third, it significantly reduces the increased costs of all hospital and medical services directly associated with untreated SDB. In short, the recognition and treatment of SDB is vital for the continued health and wellbeing of individual patients with SDB.
\end{abstract}

Keywords: Obstructive sleep apnea, Sleep-disordered breathing, Arterial hypertension, Chronic obstructive pulmonary disease, Continuous positive airway pressure, Noninvasive ventilation, Cardiovascular disease, Quality of life, Healthcare costs, Chronic diseases

\section{Background}

US data show that sleep-disordered breathing (SDB) with an apnea-hypopnea index (AHI) of $\geq 15 / \mathrm{h}$ is present in $20 \%$ of the adult population aged $30-70$ years and approximately one-third of those aged between 50 and

\footnotetext{
*Correspondence: peter.farrell@resmed.com

1 ResMed Science Center, c/o ResMed, 9001 Spectrum Center Blvd., San Diego, CA 92123, USA

Full list of author information is available at the end of the article
}

70 years [1]. Figures from a more recent European study showed that nearly $50 \%$ of males and $23 \%$ of females in a randomly selected sample of healthy patients living in Lausanne, Switzerland had moderate to severe SDB [2]. Using the same definition, data from a systematic review reported the worldwide prevalence of SDB as ranging from 6 to $49 \%$ in different patient groups, with risk factors for obstructive sleep apnea (OSA) including increasing age, male sex and higher body mass index [3]. 
These statistics are alarming given that it is now well established that untreated SDB, including obstructive sleep apnea (OSA), has been linked with, and may even contribute to the development of, some of the most debilitating and costly chronic diseases. These include most forms of cardiovascular disease [4-14], cancer, chronic obstructive pulmonary disease (COPD) [15], stroke [16, 17] and type II diabetes mellitus [18, 19], conditions associated with significant morbidity and mortality in the Western world. The prevalence of SDB/OSA in these disease states varies, with rates of $3-66 \%$ in COPD [15, 20,21 ] and approximately $75 \%$ in congestive heart failure (HF) and stroke [22-25]. Given that SDB is thought to contribute to the development and severity of many of these conditions $[5,17,18,26-29]$, untreated SDB/OSA is an important global public health problem.

This article provides an overview of current published evidence for the influence of SDB and PAP therapy on several important comorbidities, including incidence, disease progression, healthcare costs and quality of life.

\section{Pathophysiological mechanisms}

The damage caused by untreated SDB/OSA is largely a result of repetitive hypoxia due to airway obstruction, concomitant activation of sympathetic neural activity (SNA), hemodynamic disturbances and sleep disruption [30-34]. Activation of the sympathetic nervous system is associated with the release of catecholamines (epinephrine and norepinephrine), which cause vasodilation (heart and brain) or vasoconstriction (all other organs) (termed the 'fight or flight' response) up to hundreds of times per night. The physiologic effects of OSA have been associated with systemic inflammation, with OSA patients showing increased levels of key inflammatory mediators such as tumor necrosis factor-alfa, C-reactive protein, and chemokines [35-40]. Furthermore, intermittent and chronic hypoxia has been associated with glucose intolerance and insulin resistance [41, 42], and the adverse effects of hypoxia on glucose metabolism appear to be mediated via the sympathetic nervous system $[39,43]$. In addition, to effects on physiological processes, the sleep disruption associated with SDB has effects that are often very debilitating, including daytime sleepiness [44], cognitive impairment [45, 46], depression [47], relationship difficulties [48] and dementia [46] to appetite changes/obesity [49] and reduced immunity [50].

\section{Incidence and development of comorbidities}

SDB is strongly associated with several of the most important chronic diseases affecting Western societies, including cancer, cardiovascular disease, heart failure, diabetes, stroke and COPD. In each of these diseases, the adverse physiological consequences of SDB described above contribute to accelerated disease progression.

\section{Arterial hypertension}

A role for OSA in the pathogenesis of arterial hypertension has been widely documented and is recognized in international guidelines [26, 27]. However, many healthcare professionals remain unaware that OSA is a risk factor for arterial hypertension [51]. There is a strong bi-directional relationship between OSA and arterial hypertension, with about $30-40 \%$ of patients with arterial hypertension having clinically relevant OSA and approximately half of all patients with OSA having hypertension [12]. The prevalence of OSA is as high as $80 \%$ in patients with severe drug-resistant hypertension $[52,53]$, and the prevalence of arterial hypertension increases as OSA severity increases [54-61].

\section{Congestive heart failure}

SDB is believed to play a major role in congestive HF [6, 14]. The prevalence of SDB in patients with HF with preserved ejection fraction (HF $p$ EF; diastolic HF) or HF with reduced ejection fraction ( $\mathrm{HFrEF}$; systolic HF) is around $75 \%[23,25]$, and half of these patients have moderateto-severe sleep apnea [25]. OSA appears to be the predominant type of SDB in patients with $\mathrm{HF} p \mathrm{EF}$, with a prevalence of $62 \%$ compared with $18 \%$ for central sleep apnea/Cheyne Stokes respiration (CSA/CSR) [62], but prevalence rates for CSA/CSR and OSA are approximately equal in patients with $\mathrm{HF} r \mathrm{EF}$ [63]. The severity of ventricular dysfunction increases the risk for CSA/ CSR in both groups. Untreated OSA and CSA/CSR are independent risk factors for worse prognosis and death in HF patients [7-9, 13], and daytime CSR is a significant independent predictor of mortality in those with severe congestive HF [4].

\section{Arrhythmias}

Sleep apnea is highly prevalent in patients with arrhythmias, particularly atrial fibrillation (AF). More than $50 \%$ of patients with paroxysmal or persistent AF have been shown to have clinically-relevant SDB [64], and the prevalence of SDB in patients with AF presenting for electrical cardioversion is approximately 75\% [23]. Severe OSA increases the risk of AF, ventricular premature beats and non-sustained ventricular tachycardia (NSVT), and nocturnal sudden cardiac death [11]. An AHI of $>20 / h$ was a significant and independent risk factor for incident sudden cardiac death in a study of more than 10,000 patients referred for polysomnographic assessment of SDB [5]. 


\section{Coronary artery disease}

The prevalence of OSA in patients with coronary artery disease (CAD) is high (up to $87 \%$ in patients referred for coronary artery bypass graft surgery) and is significantly greater than in the general population [65-70]. The prevalence of OSA in CAD is higher than that of better known risk factors such as obesity, arterial hypertension, diabetes, or AF [71], and OSA remains a major risk factor for CAD even after controlling for other risk factors, including body mass index (BMI), hypertension, hypercholesterolemia, diabetes and smoking [29]. The Sleep Heart Health Study showed that men aged $40-70$ years with an AHI of $\geq 30 / \mathrm{h}$ were $68 \%$ more likely to develop CAD compared with those who had an AHI of $<5 / \mathrm{h}[6]$. In the recent Sleep and Stent study, OSA was a significant independent predictor of major adverse cardiac and cerebrovascular events in patients undergoing percutaneous coronary intervention (HR 1.57, 95\% CI 1.10-2.24; $\mathrm{p}=0.013)[10]$.

CAD patients with OSA have a worse prognosis than those without SDB. Cardiovascular event rates over 5-years' follow-up were 37.5 and $9.3 \%$ in CAD patients with versus without OSA, respectively $(\mathrm{p}=0.018)$, and untreated OSA was a significant independent predictor of cardiovascular mortality [72]. In another study in patients with acute coronary syndromes followed-up for a mean of 227 days, OSA was identified as an independent predictor of major cardiac events (hazard ratio [HR] 11.62, 95\% confidence interval [CI] 2.17-62.24; $\mathrm{p}=0.004)$ [73].

\section{Stroke}

The prevalence of OSA in patients with stroke is up to $71 \%$, based on data from case-control studies [22, 24]. An AHI of $\geq 20 / h$ appears to increase the risk of having a stroke [24], and severe OSA (AHI $\geq 30 / \mathrm{h}$ ) was significantly and independently associated with wake-up stroke in a prospective study [17]. OSA is also an independent risk factor for stroke recurrence [16].

\section{Diabetes mellitus}

The prevalence of type 2 diabetes mellitus is increasing rapidly worldwide, largely due to the obesity epidemic, and the vascular complications of diabetes alone are a significant burden on healthcare systems [74]. SDB is highly prevalent in patients with type 2 diabetes, with up to two-thirds having at least mild OSA [75, 76]. Data from 1387 participants in the Wisconsin Sleep Cohort identified an increasing prevalence of diabetes as the severity of SDB increased; the odds ratio for having diabetes in patients with an AHI of $\geq 15 / \mathrm{h}$ versus $<5 / \mathrm{h}$ (adjusted for age, sex and BMI) was 2.30 (95\% CI 1.28, 4.11; p = 0.005) [19]. The Sleep Heart Health Study was one of the largest community-based cohort studies utilizing polysomnography (PSG), and the results indicated that OSA was associated with impaired fasting glucose, glucose intolerance and type 2 diabetes mellitus, even when accounting for common confounding factors such as age, sex, race, waist circumference and BMI [18].

\section{Chronic obstructive pulmonary disease}

Although less common in the general population (1-4\%), the coexistence of COPD and OSA (termed 'overlap syndrome') is relatively common in patients with either disease (3-66\%) [15]. Sleep, via reduced chemosensitivity, hypotonia and supine posture, places an additional load on breathing compared with periods of wakefulness, and patients with COPD often have poor sleep quality [77]. The presence of OSA in this setting further increases breathing load and sleep disruption, and adds to the cardiovascular effects of repeated apneas. Potential mechanisms by which OSA could have a negative influence on COPD include vagally-mediated bronchoconstriction (thus augmenting expiratory airflow resistance) and increasing resistive load in the lower airways due to high negative intrathoracic pressure [78-80]. Patients with both COPD and OSA have high rates of morbidity and mortality, and poor quality of life [80-86]. In addition, the coexistence of OSA and COPD is associated with high healthcare utilisation and costs [87].

\section{Cancer}

The connection between SDB and cancer is a very interesting one and is the direct result of repetitive hypoxia. If cancer cells are exposed to repetitive hypoxia in vitro, almost instantaneous angiogenesis occurs, with proliferation of blood vessels and cancer cells [88]. In animal models of cancer, intermittent hypoxia has been linked with increased tumor cell proliferation and metastases $[89,90]$. From a clinical perspective, a 22 -year prospective study involving over 1500 subjects showed that allcause cancer mortality was increased nearly fivefold in patients with severe OSA (apnea-hypopnea index $[\mathrm{AHI}]>30 / \mathrm{h}$ ), while those with moderate-to-severe OSA (AHI 15-30/h) had a doubling of all-cause mortality [91]. In an overview of current evidence from human studies, it was concluded that study findings are largely convergent, suggesting an association between OSA and cancer, and that further research is warranted [28].

\section{Effects of treatment}

SDB/OSA can be effectively and safety treated using positive airway pressure (PAP) therapies. PAP is delivered nasally, using either a nasal mask or prongs, or a full face mask. Millions of patients worldwide already receive this therapy, which is typically delivered at a pressure of 
approximately $10 \mathrm{~cm} \mathrm{H}_{2} \mathrm{O}$ (or about $1 \%$ of atmospheric pressure). Furthermore, screening for SDB, its definitive diagnosis, and initiation of treatment can be cost effective and easy using home-based diagnosis and automated CPAP treatment, with optimal mask fitting done by a trained respiratory technician or nurse [92-94]. Since its introduction 25 years ago, CPAP has changed lives for the better in over 10 million patients worldwide.

There are few published randomised trials on the effects of treatment on disease progression because ethical considerations preclude randomization of OSA patients to no therapy for long periods in a clinical trial setting, but there are many observational studies demonstrating the benefits of CPAP therapy. Therefore, there is a considerable and growing body of evidence suggesting that effective treatment of SDB/OSA with CPAP also attenuates some of the negative consequences of untreated sleep apnea and the rate of progression of many comorbid conditions [34, 133-135, 137, 95-104]. Furthermore, it has been shown that patients compliant with PAP treatment are much less likely to use inpatient and outpatient services, resulting in substantial cost savings for the healthcare system [105-110].

\section{Arterial hypertension}

In the most recent meta-analysis of published data, which included 32 randomized controlled trials, mean reductions in daytime systolic and diastolic blood pressure (BP) with CPAP versus no treatment were 2.6 and $2.0 \mathrm{mmHg}$, respectively; corresponding night-time reductions were 3.8 and $1.8 \mathrm{mmHg}(\mathrm{p}<0.001)$ [111]. While these effects are modest, most patients in these studies had well-controlled hypertension before CPAP was initiated. Therefore, $\mathrm{BP}$ reductions during CPAP were additional to those associated with antihypertensive drug therapy, and were of a magnitude that was at least half of that achieved with drug therapy alone in similar analyses. The meta-analysis also showed a link between baseline OSA severity and the beneficial effects of CPAP on BP, with the greatest reductions seen in those with more severe OSA $(\beta \pm$ standard error, $0.08 \pm 0.04$ ) [111]. The most substantial reductions in BP during CPAP therapy have been seen in patients with drug-resistant hypertension [53]. A meta-analysis of five randomized clinical trials of CPAP in patients with OSA and resistant hypertension reported pooled reductions of 4.78 and $2.95 \mathrm{mmHg}$ in $24-\mathrm{h}$ ambulatory systolic and diastolic BP, respectively [100].

Based on combined data from three randomized trials, increases in mean office and home systolic BP after CPAP was stopped were 5.4 and $9.0 \mathrm{mmHg}$, respectively ( $\mathrm{p}<0.003$ and $\mathrm{p}<0.001$ vs on CPAP, respectively). Corresponding increases in mean diastolic $\mathrm{BP}$ were 5.0 and $7.8 \mathrm{mmHg}$ (both $\mathrm{p}<0.001$ ). The changes were described as clinically relevant by authors of the analysis [112]. In addition, there was a significant association between OSA severity and the extent of BP increase in response to CPAP withdrawal [112].

\section{Congestive heart failure}

Two randomized trials evaluating the effect of CPAP therapy in patients with OSA and HF showed significant improvements in left ventricular ejection fraction (LVEF) after 1 and 3 months and improved quality of life $[98,101]$. A Japanese cohort study documented a positive effect of CPAP treatment on survival in HF patients with OSA, and also highlighted the importance of compliance with therapy in achieving beneficial outcomes [99]. Treating OSA in patients with HF $p$ EF has been shown to improve left ventricular diastolic function [95]. The 2010 Heart Failure Society of America Comprehensive Heart Failure guidelines [113] and the 2013 American College of Cardiology Foundation (ACCF)/American Heart Association (AHA) guidelines [114] recommend that HF patients with OSA should receive treatment for sleep apnea to improve their HF status.

CPAP has limited ability to treat CSA/CSR in patients with HF [115-118], and the Canadian Positive Airway Pressure (CANPAP) study, which investigated the effect of CPAP therapy on CSA/CSR on transplantation-free survival in patients with stable HF, did not show a positive effect of therapy on either transplant-free survival or hospitalization [119]. Adaptive servo-ventilation (ASV) is a PAP therapy designed specifically to treat CSA/CSR, and is the most effective treatment for this type of SDB in HF patients [120-123].

Smaller trials of ASV have documented improvements in AHI, sleep quality, quality of life, LVEF, New York Heart Association class, oxygen uptake, natriuretic peptide levels, inflammatory markers and exercise capacity [124-127], with these results being consolidated in a recent meta-analysis [128]. The effect of ASV treatment on morbidity and mortality was investigated in the SERVE-HF study (NCT00733343) [129], which enrolled 1325 patients with chronic stable HFrEF and CSA/CSR, and finished in mid-2015 [130]. The effects of using ASV in HFrEF patients overall was disappointing, and patients with the most severe disease (LVEF $<30$ and $>50 \%$ CSR) randomized to ASV had a higher mortality rate than those in the control group [130]. Conversely, patients with an LVEF $\geq 30 \%$ appeared to fare better when randomized to ASV [130]. On the basis of these results, ASV is contraindicated in patients with $\mathrm{HFrEF}$ and LVEF $\leq 45 \%$. However, ASV still has a role in a number of other indications, including HF $p$ EF.

The cardiovascular improvements with minute ventilation-targeted ASV therapy in heart failure (CAT-HF) 
study (NCT01953874) compared the effects of targeted ASV added to optimized medical therapy compared with medical therapy alone in patients with acute decompensated HF [131]. The primary endpoint (a global rank score based on a hierarchy of death, cardiovascular hospitalizations and percent changes in 6-min walk distance at 6 months) did not differ significantly between the ASV and control groups $(\mathrm{p}=0.92)$, and there was no significant interaction between treatment and LVEF. However, a subgroup analysis suggested that ASV may improve outcomes in patients with $\mathrm{HF} p \mathrm{EF}$, and sleep apnea parameters were significantly improved by ASV in all patients [131].

\section{Arrhythmias}

The effectiveness of antiarrhythmic drugs and ablation interventions for the treatment of AF is reduced in patients with severe OSA [132]. Treatment of OSA with CPAP significantly reduces the risk of AF recurrence after ablation therapy [133], with one small study finding that the 1-year arrhythmia recurrence rate after successful cardioversion was halved when OSA was treated with CPAP [134]. In a larger study $(n=426)$, CPAP therapy was associated with a higher AF-free survival rate (71.9 vs $36.7 \%$ in untreated patients; $\mathrm{p}=0.01$ ) in patients with OSA and AF undergoing pulmonary vein isolation. The proportion of patients who were free of AF without drug treatment or repeat ablation was also significantly higher in CPAP users versus non-users [135]. Co-existing HF and SDB increases the risk of developing malignant ventricular arrhythmias [136], but this can be reduced by treating CSR with ASV [137]. Effective treatment of OSA is recommended by the electrophysiological societies of Europe and North America [138].

\section{Coronary artery disease}

Treatment of OSA with CPAP has been shown to have a beneficial effect on cardiovascular event rates and mortality in patients with coronary artery disease. In one study the risk of fatal and nonfatal cardiovascular events in OSA patients treated with CPAP was $36 \%$ lower than in untreated patients, a finding that has been repeated in studies with longer follow-up durations [96, 97, 102, 104]. However, the results of the international, multicenter sleep apnea cardiovascular endpoints (SAVE) study, conducted in non-sleepy patients with OSA and existing coronary or cerebrovascular disease, were neutral [139]. The rate of the primary endpoint (a composite of death from cardiovascular causes, myocardial infarction, stroke, or hospitalization for unstable angina, heart failure or transient ischemic attack) was similar in patients treated with CPAP + usual care and usual care alone (HR 1.10, 95\% CI 0.91-1.32; $\mathrm{p}=0.34$ ). Thus, the addition of CPAP to usual care did not reduce cardiovascular events when used as a secondary prevention intervention in OSA patients with coronary or cerebrovascular disease in this study. However, average CPAP usage was only $3.3 \mathrm{~h} / \mathrm{night}$, a level most clinicians would define as inadequate treatment. Even with usage levels this low, the CPAP group showed significantly improved daytime alertness, mood, and quality of life, and the number of self-reported work days lost due to ill-health was reduced. This is the first large sleep apnea study demonstrate that treatment with CPAP has a positive impact on depressive symptoms.

Ongoing studies (ISAACC [140] and TEAM-ASV) will determine the role of early PAP therapy after acute coronary syndrome, based on documented associations between SDB and infarct size/myocardial salvage [141] and right heart enlargement [142] after acute myocardial infarction.

\section{Stroke}

Use of CPAP in patients with stroke and OSA has been associated with improvements in subjective well-being, significant reductions in the AHI, and normalization of nocturnal BP and oxygen saturation [143-145]. A reduction in 5-year mortality has been documented in stroke patients with an AHI of $>20 / \mathrm{h}$ who tolerated CPAP compared with those who were untreated [103]. The results of these studies show that there is an increasing body of evidence that OSA plays a significant role in the overall risk management of stroke patients and that CPAP therapy can improve outcomes.

\section{Diabetes mellitus}

Treatment of OSA with CPAP has the potential to lower fasting plasma glucose, post-prandial glucose and glycosylated hemoglobin levels to at least the same extent as oral hypoglycemic agents in patients with diabetes [34]. Other beneficial effects of CPAP therapy in these patients include reductions in blood pressure, sympathetic nerve activity and arterial stiffness [146], as well as improved quality of life [147]. Reductions in cardiovascular risk seen in cohorts of OSA patients treated with CPAP would also be expected to be seen in those with diabetes. Screening and treatment of SDB is becoming incorporated in some care pathways for diabetes [148, 149], but better recognition of SDB as an important comorbidity by endocrinologists is needed.

\section{Chronic obstructive pulmonary disease}

Treatment of OSA with CPAP in patients with COPD has been shown to have a number of beneficial effects. Most importantly, use of CPAP decreased mortality in overlap syndrome patients $[83,150,151]$, with greater reductions seen as device usage time increased [151]. The rate of 
COPD exacerbations can also be reduced by CPAP treatment of OSA [83].

Noninvasive ventilation (NIV) is the standard of care for treating severe acute exacerbations of COPD and is widely used. However, until recently, there was no positive study for the effect of NIV on long-term survival in chronic stable COPD patients. A landmark trial recently showed that stable hypercapnic COPD patients treated with NIV had a two-thirds reduction in mortality and improved quality of life compared to those not receiving NIV [152]. The key point in this study was that NIV was targeted to markedly reduce hypercapnia. The benefits of NIV in patients with hypercapnic COPD were reinforced by the results of the HOT-HMV study, conducted in COPD patients with persistent hypercapnia at 2-4 weeks after an acute exacerbation [153]. This randomized, controlled trial showed that the addition of home mechanical ventilation (HMV [NIV]) to home oxygen therapy (HOT) reduced the likelihood of readmission or death by almost $50 \%$. In addition, the time to readmission or death was increased by $>90$ days. Overall, treatment of 6 patients with HMV was required to prevent 1 readmission or death. These results are consistent with the effects of NIV on other chronic diseases causing respiratory failure, and are expected to lead to significantly increased chronic use of NIV in COPD.

\section{Healthcare costs}

Several studies have demonstrated that SDB is associated with higher healthcare costs, and a consistent pattern of healthcare utilization has emerged $[105,106$, 109, 154-158]. OSA patients have higher direct medical costs for up to 10 years before diagnosis compared with those who are not diagnosed with OSA [105, 154-156], and the magnitude of difference in these costs is directly related to the severity of SDB [154]. Over this period, OSA patients develop comorbid disease, causing healthcare costs to increase rapidly, particularly in the few years before diagnosis [157]. By the time a diagnosis of OSA is made, a range of comorbid diseases (including arterial hypertension, type 2 diabetes, cardiovascular disease and/or HF) are usually established and healthcare costs are approximately double those in patients without OSA $[105,157]$.

Treatment with CPAP is most costly in the first year of therapy and direct medical costs may increase temporarily due to the cost of the device, but costs decline (or at least stop increasing at the rate before diagnosis) over subsequent years [105-110]. Established comorbidities mean that costs do not return to the levels seen in those without OSA, but costs are much lower in treated OSA patients compared to OSA patients who are not on treatment. The latter cohort have very poor outcomes and incur rapidly increasing costs as a result of advancing comorbid disease. CPAP therapy slows the rate of spending on comorbid conditions, suggesting that it does have a positive effect on disease progression.

The indirect costs of untreated OSA are higher than those for many other chronic diseases. When indirect costs are included, the societal costs of OSA are equivalent to those of stroke or congestive HF. In 2010, it was estimated that the annual cost of SDB/OSA in the US was \$US67-165 billion [159]. This is, at least in part, because OSA primarily affects a working age population and impacts on performance at work. Some effects, such as presenteeism, are difficult to measure, but the combined costs of workplace and traffic accidents, and reduced time at work due to illness mean that the indirect costs of OSA exceed direct medical costs $[160,161]$. These high indirect costs mean that CPAP therapy is particularly cost effective from a societal or self-insured employer perspective, and dominance over other strategies (better outcomes at lower cost) is achieved within a reasonable timeframe [162].

Recent cost utility studies show that CPAP becomes increasingly cost effective from year 2 of therapy onwards and is significantly below accepted thresholds for affordability by year 5 [162-167]. CPAP therapy is more cost effective than many of the preventative and treatment strategies currently used for cardiovascular diseases. It has similar cost effectiveness to aspirin for the prevention of cardiovascular disease in at-risk men [168, 169], is more cost effective than statins [170], and is considerably more cost effective than both cardiac resychronization therapy in HF [171] or catheter ablation of AF [172]. It is possible that initiating effective treatment for SDB earlier in the course of comorbid diseases would increase the cost effectiveness of therapy.

\section{Quality of life}

Poor sleep quality in OSA patients is associated with symptoms such as daytime sleepiness, tiredness, lack of concentration, memory impairment, and psychological disturbances, all of which reduce quality of life [173]. Patients with OSA have higher rates of unemployment, lower incomes, earlier retirement and higher rates of divorce than those without OSA [109]. Treatment with CPAP rapidly and reliably improves sleep architecture, reduces symptoms and improves quality of life $[109,174]$.

Patients with the worst symptoms arguably have the most to gain from PAP therapy, but those with mild disease and minimal symptoms can also show significant improvements during CPAP therapy, as shown in a UK study in which subjects who had proven OSA but insufficient symptoms (as judged by themselves and their physician) to justify treatment were randomized to CPAP or 
standard care [175]. Patients treated with CPAP experienced clinically significant improvements in both sleepiness and quality of life. These results suggest that clinical assessment of patients with OSA does not reliably identify all those likely to benefit from therapy, and that all patients with OSA, not just those who complain of symptoms, should be offered and can benefit from CPAP treatment.

\section{Conclusion}

The high prevalence of SDB, and its direct connection with many diseases which cause significant morbidity and mortality in Western societies, along with the documented ability of positive airway pressure to improve quality of life, prevent or slow progression of a wide range of common chronic diseases, and reduce healthcare resource use and costs suggest that the recognition and treatment of SDB could be described as the 'holy grail' of healthcare. Currently available data provide an excellent rationale for diagnosing and treating SDB/OSA, and for the inclusion of SDB screening and treatment in disease management pathways for the chronic diseases with which it is often associated. SDB/OSA can be easily and effectively treated with CPAP that, as has been stated, improves quality of life, slows and may even reverse the progression of associated chronic diseases, and significantly reduces both hospital and medical healthcare costs. In short, the screening, recognition and treatment of SDB should be a central component of chronic disease management programs.

\begin{abstract}
Abbreviations
AF: atrial fibrillation; AHI: apnea-hypopnea index; ASV: adaptive servo-ventilation; BMI: body mass index; BP: blood pressure; CAD: coronary artery disease; COPD: chronic obstructive pulmonary disease; CPAP: continuous positive airway pressure; CSA: central sleep apnea; CSR: Cheyne-Stokes respiration; HF: heart failure; HFpEF: heart failure with preserved ejection fraction; HFrEF: heart failure with reduced ejection fraction; LVEF: left ventricular ejection fraction; NIV: noninvasive ventilation; NSVT: non-sustained ventricular tachycardia; OSA: obstructive sleep apnea; PAP: positive airway pressure; SDB: sleep-disordered breathing; SNA: sympathetic neural activity.
\end{abstract}

\section{Authors' contributions}

PF carried out the literature search, and PF and GR participated in the literature analysis. The first draft of the manuscript was written by PF, with critical revisions for intellectual content undertaken by GR. Both authors read and approved the final manuscript.

\section{Author details}

${ }^{1}$ ResMed Science Center, c/o ResMed, 9001 Spectrum Center Blvd., San Diego, CA 92123, USA. ${ }^{2}$ ResMed Science Center, Sydney, Australia.

\section{Acknowledgements}

Editing assistance was provided by Nicola Ryan, independent medical writer, funded by ResMed.

\section{Competing interests}

Peter Farrell and Glenn Richards are employees of ResMed Ltd.

\section{Availability of data and materials}

The authors will share source documents used in compiling the review manuscript. The datasets supporting the conclusions of this article are included within the article.

\section{Consent for publication}

The authors consent to publish the manuscript.

\section{Ethics approval and consent to participate}

The manuscript is a review of published literature and did not involve human or animal experimentation.

Funding

The authors of the review manuscript were funded by ResMed Ltd.

\section{Publisher's Note}

Springer Nature remains neutral with regard to jurisdictional claims in published maps and institutional affiliations.

Received: 29 March 2017 Accepted: 13 May 2017

Published online: 25 May 2017

References

1. Peppard PE, Young T, Barnet JH, Palta M, Hagen EW, Hla KM. Increased prevalence of sleep-disordered breathing in adults. Am J Epidemiol. 2013;177(9):1006-14.

2. Heinzer R, Vat S, Marques-Vidal P, Marti-Soler H, Andries D, Tobback N, et al. Prevalence of sleep-disordered breathing in the general population: the HypnoLaus study. Lancet Respir Med. 2015;3(4):310-8.

3. Senaratna CV, Perret JL, Lodge CJ, Lowe AJ, Campbell BE, Matheson MC, et al. Prevalence of obstructive sleep apnea in the general population: a systematic review. Sleep Med Rev. 2016. doi:10.1016/j.smrv.2016.07.002 (Epub ahead of print)

4. Brack T, Thuer I, Clarenbach CF, Senn O, Noll G, Russi EW, et al. Daytime Cheyne-Stokes respiration in ambulatory patients with severe congestive heart failure is associated with increased mortality. Chest. 2007;132(5):1463-71.

5. Gami AS, Olson EJ, Shen WK, Wright RS, Ballman KV, Hodge DO, et al. Obstructive sleep apnea and the risk of sudden cardiac death: a longitudinal study of 10,701 adults. J Am Coll Cardiol. 2013:62(7):610-6.

6. Gottlieb DJ, Yenokyan G, Newman AB, O'Connor GT, Punjabi NM, Quan SF, et al. Prospective study of obstructive sleep apnea and incident coronary heart disease and heart failure: the Sleep Heart Health Study. Circulation. 2010;122(4):352-60.

7. Javaheri S, Shukla R, Zeigler H, Wexler L. Central sleep apnea, right ventricular dysfunction, and low diastolic blood pressure are predictors of mortality in systolic heart failure. J Am Coll Cardiol. 2007;49(20):2028-34.

8. Jilek C, Krenn M, Sebah D, Obermeier R, Braune A, Kehl V, et al. Prognostic impact of sleep disordered breathing and its treatment in heart failure: an observational study. Eur J Heart Fail. 2011;13(1):68-75.

9. Khayat R, Abraham W, Patt B, Brinkman V, Wannemacher J, Porter K, et al. Central sleep apnea is a predictor of cardiac readmission in hospitalized patients with systolic heart failure. J Card Fail. 2012;18(7):534-40.

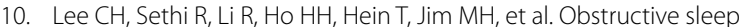
apnea and cardiovascular events after percutaneous coronary intervention. Circulation. 2016;133(21):2008-17.

11. Mehra R, Benjamin EJ, Shahar E, Gottlieb DJ, Nawabit R, Kirchner HL, et al. Association of nocturnal arrhythmias with sleep-disordered breathing: the Sleep Heart Health Study. Am J Respir Crit Care Med. 2006;173(8):910-6.

12. Somers VK, White DP, Amin R, Abraham WT, Costa F, Culebras A, et al. Sleep apnea and cardiovascular disease: an American Heart Association/American College of Cardiology Foundation Scientific Statement from the American Heart Association Council for High Blood Pressure Research Professional Education Committee, Council on Clinical 
Cardiology, Stroke Council, and Council on Cardiovascular Nursing. J Am Coll Cardiol. 2008;52(8):686-717.

13. Wang H, Parker JD, Newton GE, Floras JS, Mak S, Chiu KL, et al. Influence of obstructive sleep apnea on mortality in patients with heart failure. J Am Coll Cardiol. 2007:49(15):1625-31.

14. Shahar E, Whitney CW, Redline S, Lee ET, Newman AB, Nieto FJ, et al. Sleep-disordered breathing and cardiovascular disease: cross-sectional results of the Sleep Heart Health Study. Am J Respir Crit Care Med. 2001;163(1):19-25.

15. Shawon MS, Perret JL, Senaratna CV, Lodge C, Hamilton GS, Dharmage SC. Current evidence on prevalence and clinical outcomes of co-morbid obstructive sleep apnea and chronic obstructive pulmonary disease: a systematic review. Sleep Med Rev. 2017;32:58-68.

16. Dziewas R, Humpert M, Hopmann B, Kloska SP, Ludemann P, Ritter M, et al. Increased prevalence of sleep apnea in patients with recurring ischemic stroke compared with first stroke victims. J Neurol. 2005;252(11):1394-8.

17. Hsieh SW, Lai CL, Liu CK, Hsieh CF, Hsu CY. Obstructive sleep apnea linked to wake-up strokes. J Neurol. 2012;259(7):1433-9.

18. Punjabi NM, Shahar E, Redline S, Gottlieb DJ, Givelber R, Resnick $H E$, et al. Sleep-disordered breathing, glucose intolerance, and insulin resistance: the Sleep Heart Health Study. Am J Epidemiol. 2004;160(6):521-30

19. Reichmuth KJ, Austin D, Skatrud JB, Young T. Association of sleep apnea and type II diabetes: a population-based study. Am J Respir Crit Care Med. 2005:172(12):1590-5.

20. Soler X, Gaio E, Powell FL, Ramsdell JW, Loredo JS, Malhotra A, et al. High prevalence of obstructive sleep apnea in patients with moderate to severe chronic obstructive pulmonary disease. Ann Am Thorac Soc. 2015;12(8):1219-25

21. Agarwal A, Zhang W, Kuo Y-F, Sharma G. A population based study of prevalenc of OSA in patients with COPD: the overlap syndrome. Chest. 2016;150(4_S):843A

22. Arzt M, Young T, Finn L, Skatrud JB, Bradley TD. Association of sleepdisordered breathing and the occurrence of stroke. Am J Respir Crit Care Med. 2005;172(11):1447-51.

23. Bitter $T$, Faber $L$, Hering D, Langer $C$, Horstkotte D, Oldenburg $O$. Sleep-disordered breathing in heart failure with normal left ventricular ejection fraction. Eur J Heart Fail. 2009;1 1(6):602-8.

24. Im KB, Strader S, Dyken ME. Management of sleep disorders in stroke. Curr Treat Options Neurol. 2010;12(5):379-95.

25. Oldenburg O, Lamp B, Faber L, Teschler H, Horstkotte D, Topfer V. Sleepdisordered breathing in patients with symptomatic heart failure: a contemporary study of prevalence in and characteristics of 700 patients. Eur J Heart Fail. 2007;9(3):251-7.

26. Chobanian AV, Bakris GL, Black HR, Cushman WC, Green LA, Izzo JL Jr, et al. The seventh report of the joint national committee on prevention, detection, evaluation, and treatment of high blood pressure: the JNC 7 report. JAMA. 2003;289(19):2560-72.

27. Mancia G, De Backer G, Dominiczak A, Cifkova R, Fagard R, Germano G, et al. 2007 guidelines for the management of arterial hypertension: the task force for the management of arterial hypertension of the European Society of Hypertension (ESH) and of the European Society of Cardiology (ESC). J Hypertens. 2007;25(6):1105-87.

28. Martinez-Garcia MA, Campos-Rodriguez F, Barbe F. Cancer and OSA current evidence from human studies. Chest. 2016;150(2):451-63.

29. Peker Y, Carlson J, Hedner J. Increased incidence of coronary artery disease in sleep apnoea: a long-term follow-up. Eur Respir J. 2006;28(3):596-602.

30. Bagai K. Obstructive sleep apnea, stroke, and cardiovascular diseases. Neurologist. 2010;16(6):329-39.

31. Bradley TD, Floras JS. Obstructive sleep apnoea and its cardiovascular consequences. Lancet. 2009;373(9657):82-93.

32. Leung RS, Comondore VR, Ryan CM, Stevens D. Mechanisms of sleep-disordered breathing: causes and consequences. Pflugers Arch 2012:463(1):213-30

33. Sharma S, Kavuru M. Sleep and metabolism: an overview. Int J Endocrinol. 2010;2010(2010):270832.

34. Tasali E, Ip MS. Obstructive sleep apnea and metabolic syndrome: alterations in glucose metabolism and inflammation. Proc Am Thorac Soc. 2008;5(2):207-17.
35. Kokturk O, Ciftci TU, Mollarecep E, Ciftci B. Elevated C-reactive protein levels and increased cardiovascular risk in patients with obstructive sleep apnea syndrome. Int Heart J. 2005;46(5):801-9.

36. Minoguchi K, Tazaki T, Yokoe T, Minoguchi H, Watanabe Y, Yamamoto $M$, et al. Elevated production of tumor necrosis factor-alpha by monocytes in patients with obstructive sleep apnea syndrome. Chest. 2004;126(5):1473-9.

37. Ohga E, Tomita T, Wada H, Yamamoto H, Nagase T, Ouchi Y. Effects of obstructive sleep apnea on circulating ICAM-1, IL-8, and MCP-1. J Appl Physiol. 2003;94(1):179-84.

38. Ryan S, Taylor CT, McNicholas WT. Selective activation of inflammatory pathways by intermittent hypoxia in obstructive sleep apnea syndrome. Circulation. 2005;112(17):2660-7.

39. Shamsuzzaman AS, Winnicki M, Lanfranchi P, Wolk R, Kara T, Accurso $V$, et al. Elevated $C$-reactive protein in patients with obstructive sleep apnea. Circulation. 2002;105(21):2462-4.

40. Yokoe T, Minoguchi K, Matsuo H, Oda N, Minoguchi H, Yoshino G, et al. Elevated levels of $\mathrm{C}$-reactive protein and interleukin- 6 in patients with obstructive sleep apnea syndrome are decreased by nasal continuous positive airway pressure. Circulation. 2003;107(8):1129-34.

41. Drager LF, Li J, Reinke C, Bevans-Fonti S, Jun JC, Polotsky VY. Intermittent hypoxia exacerbates metabolic effects of diet-induced obesity. Obesity. 2011;19(11):2167-74.

42. Polotsky VY, Li J, Punjabi NM, Rubin AE, Smith PL, Schwartz AR, et al. Intermittent hypoxia increases insulin resistance in genetically obese mice. J Physiol. 2003:552(Pt 1):253-64.

43. Shin MK, Han W, Bevans-Fonti S, Jun JC, Punjabi NM, Polotsky VY. The effect of adrenal medullectomy on metabolic responses to chronic intermittent hypoxia. Respir Physiol Neurobiol. 2014;203:60-7.

44. Kapur VK, Baldwin CM, Resnick HE, Gottlieb DJ, Nieto FJ. Sleepiness in patients with moderate to severe sleep-disordered breathing. Sleep. 2005;28(4):472-7.

45. Canessa N, Castronovo V, Cappa SF, Aloia MS, Marelli S, Falini A, et al. Obstructive sleep apnea: brain structural changes and neurocognitive function before and after treatment. Am J Respir Crit Care Med. 2011;183(10):1419-26.

46. Gagnon K, Baril AA, Gagnon JF, Fortin M, Decary A, Lafond C, et al. Cognitive impairment in obstructive sleep apnea. Pathol Biol. 2014;62(5):233-40.

47. Harris M, Glozier N, Ratnavadivel R, Grunstein RR. Obstructive sleep apnea and depression. Sleep Med Rev. 2009;13(6):437-44.

48. Reishtein JL, Maislin G, Weaver TE. Multisite Study Group. Outcome of CPAP treatment on intimate and sexual relationships in men with obstructive sleep apnea. J Clin Sleep Med. 2010;6(3):221-6.

49. Beccuti G, Pannain S. Sleep and obesity. Curr Opin Clin Nutr Metab Care. 2011;14(4):402-12.

50. Freire AX, Kadaria D, Avecillas JF, Murillo LC, Yataco JC. Obstructive sleep apnea and immunity: relationship of lymphocyte count and apnea hypopnea index. South Med J. 2010;103(8):771-4.

51. Sharma S, Srijithesh PR. Sleeping over a sleep disorder-awareness of obstructive sleep apnoea as a modifiable risk factor for hypertension and stroke: a survey among health care professionals and medical students. Ann Indian Acad Neurol. 2013;16(2):151-3.

52. Logan AG, Tkacova R, Perlikowski SM, Leung RS, Tisler A, Floras JS, et al. Refractory hypertension and sleep apnoea: effect of CPAP on blood pressure and baroreflex. Eur Respir J. 2003;21(2):241-7.

53. Pedrosa RP, Drager LF, de Paula LK, Amaro AC, Bortolotto LA, LorenziFilho G. Effects of obstructive sleep apnea treatment on blood pressure in patients with resistant hypertension: a randomized trial. Chest J. 2013;144:1487-94.

54. Guillot M, Sforza E, Achour-Crawford E, Maudoux D, Saint-Martin M, Barthelemy JC, et al. Association between severe obstructive sleep apnea and incident arterial hypertension in the older people population. Sleep Med. 2013;14(9):838-42.

55. Hla KM, Young T, Finn L, Peppard PE, Szklo-Coxe M, Stubbs M. Longitudinal association of sleep-disordered breathing and nondipping of nocturnal blood pressure in the Wisconsin Sleep Cohort Study. Sleep. 2008;31 (6):795-800.

56. Hla KM, Young TB, Bidwell T, Palta M, Skatrud JB, Dempsey J. Sleep apnea and hypertension. A population-based study. Ann Intern Med. 1994;120(5):382-8. 
57. Lavie $P$, Herer $P$, Hoffstein $V$. Obstructive sleep apnoea syndrome as a risk factor for hypertension: population study. BMJ. 2000;320(7233):479-82.

58. Marin JM, Agusti A, Villar I, Forner M, Nieto D, Carrizo SJ, et al. Association between treated and untreated obstructive sleep apnea and risk of hypertension. JAMA. 2012;307(20):2169-76.

59. Nieto FJ, Young TB, Lind BK, Shahar E, Samet JM, Redline S, et al. Association of sleep-disordered breathing, sleep apnea, and hypertension in a large community-based study. Sleep Heart Health Study. JAMA. 2000;283(14):1829-36.

60. Peppard PE, Young T, Palta M, Skatrud J. Prospective study of the association between sleep-disordered breathing and hypertension. N Engl J Med. 2000;342(19):1378-84.

61. Young T, Peppard P, Palta M, Hla KM, Finn L, Morgan B, et al. Populationbased study of sleep-disordered breathing as a risk factor for hypertension. Arch Intern Med. 1997;157(15):1746-52.

62. Herrscher TE, Akre H, Overland B, Sandvik L, Westheim AS. High prevalence of sleep apnea in heart failure outpatients: even in patients with preserved systolic function. J Card Fail. 2011;17(5):420-5.

63. Noda A, Miyata S, Yasuda Y. Therapeutic strategies for sleep apnea in hypertension and heart failure. Pulm Med. 2013;2013:814169.

64. Bitter T, Westerheide N, Faber L, Hering D, Prinz C, Langer C, et al. Adaptive servoventilation in diastolic heart failure and Cheyne-Stokes respiration. Eur Respir J. 2010;36(2):385-92.

65. Andreas S, Schulz R, Werner GS, Kreuzer H. Prevalence of obstructive sleep apnoea in patients with coronary artery disease. Coron Artery Dis. 1996;7(7):541-5.

66. Danzi-Soares NJ, Genta PR, Nerbass FB, Pedrosa RP, Soares FS, Cesar $L A$, et al. Obstructive sleep apnea is common among patients referred for coronary artery bypass grafting and can be diagnosed by portable monitoring. Coron Artery Dis. 2012;23(1):31-8.

67. Lee $\mathrm{CH}$, Khoo SM, Tai BC, Chong EY, Lau C, Than Y, et al. Obstructive sleep apnea in patients admitted for acute myocardial infarction. Prevalence, predictors, and effect on microvascular perfusion. Chest. 2009;135(6):1488-95.

68. Mooe T, Rabben T, Wiklund U, Franklin KA, Eriksson P. Sleepdisordered breathing in men with coronary artery disease. Chest. 1996:109(3):659-63.

69. Mooe T, Rabben T, Wiklund U, Franklin KA, Eriksson P. Sleep-disordered breathing in women: occurrence and association with coronary artery disease. Am J Med. 1996;101(3):251-6.

70. Nakashima H, Katayama T, Takagi C, Amenomori K, Ishizaki M, Honda Y, et al. Obstructive sleep apnoea inhibits the recovery of left ventricular function in patients with acute myocardial infarction. Eur Heart J. 2006;27(19):2317-22.

71. Glantz H, Thunstrom E, Herlitz J, Cederin B, Nasic S, Ejdeback J, et al. Occurrence and predictors of obstructive sleep apnea in a revascularized coronary artery disease cohort. Ann Am Thorac Soc. 2013;10(4):350-6

72. Peker $Y$, Hedner J, Kraiczi H, Loth S. Respiratory disturbance index: an independent predictor of mortality in coronary artery disease. Am J Respir Crit Care Med. 2000;162(1):81-6.

73. Yumino D, Tsurumi Y, Takagi A, Suzuki K, Kasanuki H. Impact of obstructive sleep apnea on clinical and angiographic outcomes following percutaneous coronary intervention in patients with acute coronary syndrome. Am J Cardiol. 2007;99(1):26-30.

74. van Dieren S, Beulens JW, van der Schouw YT, Grobbee DE, Neal B. The global burden of diabetes and its complications: an emerging pandemic. Eur J Cardiovasc Prev Rehabil. 2010;17(Suppl 1):S3-8.

75. Foster GD, Sanders MH, Millman R, Zammit G, Borradaile KE, Newman $A B$, et al. Obstructive sleep apnea among obese patients with type 2 diabetes. Diabetes Care. 2009;32(6):1017-9.

76. Resnick HE, Jones K, Ruotolo G, Jain AK, Henderson J, Lu W, et al. Insulin resistance, the metabolic syndrome, and risk of incident cardiovascular disease in nondiabetic american indians: the Strong Heart Study. Diabetes Care. 2003;26(3):861-7.

77. Chang CH, Chuang LP, Lin SW, Lee CS, Tsai YH, Wei YF, et al. Factors responsible for poor sleep quality in patients with chronic obstructive pulmonary disease. BMC Pulm Med. 2016;16(1):118.

78. Ioachimescu OC, Teodorescu M. Integrating the overlap of obstructive lung disease and obstructive sleep apnoea: OLDOSA syndrome. Respirology. 2013;18(3):421-31.
79. McNicholas WT. Chronic obstructive pulmonary disease and obstructive sleep apnea: overlaps in pathophysiology, systemic inflammation, and cardiovascular disease. Am J Respir Crit Care Med. 2009;180(8):692-700.

80. Ganga HV, Nair SU, Puppala VK, Miller WL. Risk of new-onset atrial fibrillation in elderly patients with the overlap syndrome: a retrospective cohort study. J Geriatr Cardiol. 2013;10(2):129-34.

81. Chaouat A, Weitzenblum E, Krieger J, Ifoundza T, Oswald M, Kessler R. Association of chronic obstructive pulmonary disease and sleep apnea syndrome. Am J Respir Crit Care Med. 1995;151(1):82-6.

82. Hawrylkiewicz I, Sliwinski P, Gorecka D, Plywaczewski R, Zielinski J. Pulmonary haemodynamics in patients with OSAS or an overlap syndrome. Monaldi Arch Chest Dis. 2004;61(3):148-52.

83. Marin JM, Soriano JB, Carrizo SJ, Boldova A, Celli BR. Outcomes in patients with chronic obstructive pulmonary disease and obstructive sleep apnea: the overlap syndrome. Am J Respir Crit Care Med. 2010;182(3):325-31.

84. Mermigkis C, Kopanakis A, Foldvary-Schaefer N, Golish J, Polychronopoulos $V$, Schiza $S$, et al. Health-related quality of life in patients with obstructive sleep apnoea and chronic obstructive pulmonary disease (overlap syndrome). Int J Clin Pract. 2007;61(2):207-11.

85. Sharma B, Neilan TG, Kwong RY, Mandry D, Owens RL, McSharry D, et al. Evaluation of right ventricular remodeling using cardiac magnetic resonance imaging in co-existent chronic obstructive pulmonary disease and obstructive sleep apnea. COPD. 2013;10(1):4-10.

86. Zohal MA, Yazdi Z, Kazemifar AM, Mahjoob P, Ziaeeha M. Sleep quality and quality of life in COPD Patients with and without suspected obstructive sleep apnea. Sleep Disord. 2014;2014:508372.

87. Shaya FT, Lin PJ, Aljawadi MH, Scharf SM. Elevated economic burden in obstructive lung disease patients with concomitant sleep apnea syndrome. Sleep Breath. 2009;13(4):317-23.

88. Harris AL. Hypoxia-a key regulatory factor in tumour growth. Nat Rev Cancer. 2002;2(1):38-47.

89. Almendros I, Montserrat JM, Torres M, Dalmases M, Cabanas ML, Campos-Rodriguez F, et al. Intermittent hypoxia increases melanoma metastasis to the lung in a mouse model of sleep apnea. Respir Physiol Neurobiol. 2013;186(3):303-7.

90. Almendros I, Wang Y, Becker L, Lennon FE, Zheng J, Coats BR, et al. Intermittent hypoxia-induced changes in tumor-associated macrophages and tumor malignancy in a mouse model of sleep apnea. Am J Respir Crit Care Med. 2014;189(5):593-601.

91. Nieto FJ, Peppard PE, Young T, Finn L, Hla KM, Farre R. Sleep-disordered breathing and cancer mortality: results from the Wisconsin Sleep Cohort Study. Am J Respir Crit Care Med. 2012;186(2):190-4.

92. Kim RD, Kapur VK, Redline-Bruch J, Rueschman M, Auckley DH, Benca RM, et al. An economic evaluation of home versus laboratory-based diagnosis of obstructive sleep apnea. Sleep. 2015:38(7):1027-37.

93. Masa JF, Corral J, Sanchez de Cos J, Duran-Cantolla J, Cabello M, Hernandez-Blasco L, et al. Effectiveness of three sleep apnea management alternatives. Sleep. 2013;36(12):1799-807.

94. Pietzsch JB, Garner A, Cipriano LE, Linehan JH. An integrated healtheconomic analysis of diagnostic and therapeutic strategies in the treatment of moderate-to-severe obstructive sleep apnea. Sleep. 2011;34(6):695-709.

95. Arias MA, Garcia-Rio F, Alonso-Fernandez A, Mediano O, Martinez I, Villamor J. Obstructive sleep apnea syndrome affects left ventricular diastolic function: effects of nasal continuous positive airway pressure in men. Circulation. 2005;112(3):375-83.

96. Cassar A, Morgenthaler TI, Lennon RJ, Rihal CS, Lerman A. Treatment of obstructive sleep apnea is associated with decreased cardiac death after percutaneous coronary intervention. J Am Coll Cardiol. 2007:50(14):1310-4.

97. Garcia-Rio F, Alonso-Fernandez A, Armada E, Mediano O, Lores V, Rojo $B$, et al. CPAP effect on recurrent episodes in patients with sleep apnea and myocardial infarction. Int J Cardiol. 2013;168(2):1328-35.

98. Kaneko Y, Floras JS, Usui K, Plante J, Tkacova R, Kubo T, et al. Cardiovascular effects of continuous positive airway pressure in patients with heart failure and obstructive sleep apnea. N Engl J Med. 2003;348(13):1233-41.

99. Kasai T, Narui K, Dohi T, Yanagisawa N, Ishiwata S, Ohno M, et al. Prognosis of patients with heart failure and obstructive sleep apnea treated with continuous positive airway pressure. Chest. 2008;133(3):690-6. 
100. Liu L, Cao Q, Guo Z, Dai Q. Continuous positive airway pressure in patients with obstructive sleep apnea and resistant hypertension: a meta-analysis of randomized controlled trials. J Clin Hypertens. 2016;18(2):153-8.

101. Mansfield DR, Gollogly NC, Kaye DM, Richardson M, Bergin P, Naughton MT. Controlled trial of continuous positive airway pressure in obstructive sleep apnea and heart failure. Am J Respir Crit Care Med. 2004;169(3):361-6.

102. Marin JM, Carrizo SJ, Vicente E, Agusti AG. Long-term cardiovascular outcomes in men with obstructive sleep apnoea-hypopnoea with or without treatment with continuous positive airway pressure: an observational study. Lancet. 2005;365(9464):1046-53.

103. Martinez-Garcia MA, Soler-Cataluna JJ, Ejarque-Martinez L, Soriano Y, Roman-Sanchez P, Illa FB, et al. Continuous positive airway pressure treatment reduces mortality in patients with ischemic stroke and obstructive sleep apnea: a 5-year follow-up study. Am J Respir Crit Care Med. 2009;180(1):36-41

104. Milleron O, Pilliere R, Foucher A, de Roquefeuil F, Aegerter P, Jondeau G, et al. Benefits of obstructive sleep apnoea treatment in coronary artery disease: a long-term follow-up study. Eur Heart J. 2004;25(9):728-34.

105. Albarrak M, Banno K, Sabbagh AA, Delaive K, Walld R, Manfreda J, et al. Utilization of healthcare resources in obstructive sleep apnea syndrome: a 5-year follow-up study in men using CPAP. Sleep. 2005;28(10):1306-11.

106. Bahammam A, Delaive K, Ronald J, Manfreda J, Roos L, Kryger MH. Health care utilization in males with obstructive sleep apnea syndrome two years after diagnosis and treatment. Sleep. 1999;22(6):740-7.

107. Cai Q, Tan H, Singer J. Impact of positive airway pressure among obstructive sleep apnea patients. Am J Manag Care. 2012;18(6):e225-33

108. Hoffman B, Wingenbach DD, Kagey AN, Schaneman JL, Kasper D. The long-term health plan and disability cost benefit of obstructive sleep apnea treatment in a commercial motor vehicle driver population. J Occup Environ Med. 2010;52(5):473-7.

109. Jennum P, Kjellberg J. Health, social and economical consequences of sleep-disordered breathing: a controlled national study. Thorax. 2011;66(7):560-6.

110. Potts KJ, Butterfield DT, Sims P, Henderson M, Shames CB. Cost savings associated with an education campaign on the diagnosis and management of sleep-disordered breathing: a retrospective, claims-based US study. Popul Health Manag. 2013;16(1):7-13.

111. Fava C, Dorigoni S, Dalle Vedove F, Danese E, Montagnana M, Guidi GC, et al. Effect of CPAP on blood pressure in patients with OSA/hypopnea a systematic review and meta-analysis. Chest. 2014;145(4):762-71.

112. Schwarz El, Schlatzer C, Rossi VA, Stradling JR, Kohler M. Effect of CPAPwithdrawal on blood pressure in OSA: data from three randomizedcontrolled trials. Chest. 2016;150:1202-10.

113. Heart Failure Society of A, Lindenfeld J, Albert NM, Boehmer JP, Collins SP, Ezekowitz JA, et al. HFSA 2010 comprehensive heart failure practice guideline. J Card Fail. 2010;16(6):e1-194.

114. Writing Committee M, Yancy CW, Jessup M, Bozkurt B, Butler J, Casey DE Jr, et al. 2013 ACCF/AHA guideline for the management of heart failure: a report of the American College of Cardiology Foundation/American Heart Association Task Force on practice guidelines. Circulation. 2013:128(16):e240-327.

115. Bradley TD, Floras JS. Sleep apnea and heart failure: part II: central sleep apnea. Circulation. 2003:107(13):1822-6.

116. Naughton MT, Rahman MA, Hara K, Floras JS, Bradley TD. Effect of continuous positive airway pressure on intrathoracic and left ventricular transmural pressures in patients with congestive heart failure. Circulation. 1995;91(6):1725-31.

117. Sin DD, Logan AG, Fitzgerald FS, Liu PP, Bradley TD. Effects of continuous positive airway pressure on cardiovascular outcomes in heart failure patients with and without Cheyne-Stokes respiration. Circulation. 2000;102(1):61-6

118. Takasaki Y, Orr D, Popkin J, Rutherford R, Liu P, Bradley TD. Effect of nasal continuous positive airway pressure on sleep apnea in congestive heart failure. Am Rev Respir Dis. 1989;140(6):1578-84

119. Arzt M, Floras JS, Logan AG, Kimoff RJ, Series F, Morrison D, et al. Suppression of central sleep apnea by continuous positive airway pressure and transplant-free survival in heart failure: a post hoc analysis of the Canadian Continuous Positive Airway Pressure for Patients with Central Sleep Apnea and Heart Failure Trial (CANPAP). Circulation. 2007;115(25):3173-80.

120. Teschler H, Dohring J, Wang YM, Berthon-Jones M. Adaptive pressure support servo-ventilation: a novel treatment for Cheyne-Stokes respiration in heart failure. Am J Respir Crit Care Med. 2001;164(4):614-9.

121. D’Elia E, Vanoli E, La Rovere MT, Fanfulla F, Maggioni A, Casali V, et al. Adaptive servo ventilation reduces central sleep apnea in chronic heart failure patients: beneficial effects on autonomic modulation of heart rate. J Cardiovasc Med. 2013;14(4):296-300.

122. Fietze I, Blau A, Glos M, Theres H, Baumann G, Penzel T. Bi-level positive pressure ventilation and adaptive servo ventilation in patients with heart failure and Cheyne-Stokes respiration. Sleep Med. 2008;9(6):652-9.

123. Oldenburg O, Bitter T, Prib N, et al. Performance of ASV and enhanced ASV in HF patients with CSA. Sleep. 2012;35(Suppl):A176.

124. Oldenburg O, Bitter T, Vogt J, Fischbach T, Dimitriadis Z, Bullert K, et al. Central and obstructive sleep apnea are associated with increased mortality in patients with long-term cardiac resynchronization therapy. J Am Coll Cardiol. 2011;54(Suppl. A):E100.

125. Oldenburg O, Bitter T, Wellmann B, Fischbach T, Efken C, Schmidt A, et al. Trilevel adaptive servoventilation for the treatment of central and mixed sleep apnea in chronic heart failure patients. Sleep Med. 2013;14(5):422-7.

126. Owada T, Yoshihisa A, Yamauchi H, Iwaya S, Suzuki S, Yamaki T, et al. Adaptive servoventilation improves cardiorenal function and prognosis in heart failure patients with chronic kidney disease and sleep-disordered breathing. J Card Fail. 2013;19(4):225-32.

127. Pepperell JC, Maskell NA, Jones DR, Langford-Wiley BA, Crosthwaite N, Stradling JR, et al. A randomized controlled trial of adaptive ventilation for Cheyne-Stokes breathing in heart failure. Am J Respir Crit Care Med. 2003;168(9):1109-14.

128. Sharma BK, Bakker JP, McSharry DG, Desai AS, Javaheri S, Malhotra A Adaptive servoventilation for treatment of sleep-disordered breathing in heart failure: a systematic review and meta-analysis. Chest. 2012;142(5):1211-21.

129. Cowie MR, Woehrle H, Wegscheider K, Angermann C, d'Ortho MP, Erdmann E, et al. Rationale and design of the SERVE-HF study: treatment of sleep-disordered breathing with predominant central sleep apnoea with adaptive servo-ventilation in patients with chronic heart failure. Eur J Heart Fail. 2013;15(8):937-43

130. Cowie MR, Woehrle H, Wegscheider K, Angermann C, d'Ortho MP, Erdmann E, et al. Adaptive servo-ventilation for central sleep apnea in systolic heart failure. N Engl J Med. 2015;373(12):1095-105.

131. O'Connor CM, Whellan DJ, Fiuzat M, Punjabi NM, Tasissa G, Anstrom KJ, et al. Cardiovascular outcomes with minute ventilation-targeted adaptive servo-ventilation therapy in heart failure: the CAT-HF trial. J Am Coll Cardiol. 2017;69(12):1577-87.

132. Monahan K, Brewster J, Wang L, Parvez B, Goyal S, Roden DM, et al. Relation of the severity of obstructive sleep apnea in response to antiarrhythmic drugs in patients with atrial fibrillation or atrial flutter. Am J Cardiol. 2012;110(3):369-72

133. Patel D, Mohanty P, Di Biase L, Shaheen M, Lewis WR, Quan K, et al. Safety and efficacy of pulmonary vein antral isolation in patients with obstructive sleep apnea: the impact of continuous positive airway pressure. Circ Arrhythm Electrophysiol. 2010;3(5):445-51.

134. Kanagala R, Murali NS, Friedman PA, Ammash NM, Gersh BJ, Ballman KV, et al. Obstructive sleep apnea and the recurrence of atrial fibrillation. Circulation. 2003;107(20):2589-94.

135. Fein AS, Shvilkin A, Shah D, Haffajee Cl, Das S, Kumar K, et al. Treatment of obstructive sleep apnea reduces the risk of atrial fibrillation recurrence after catheter ablation. J Am Coll Cardiol. 2013:62(4):300-5.

136. Bitter T, Westerheide N, Prinz C, Hossain MS, Vogt J, Langer C, et al. Cheyne-Stokes respiration and obstructive sleep apnoea are independent risk factors for malignant ventricular arrhythmias requiring appropriate cardioverter-defibrillator therapies in patients with congestive heart failure. Eur Heart J. 2011;32(1):61-74.

137. Bitter T, Gutleben KJ, Nolker G, Westerheide N, Prinz C, Dimitriadis $Z$, et al. Treatment of Cheyne-Stokes respiration reduces arrhythmic events in chronic heart failure. J Cardiovasc Electrophysiol. 2013:24(10):1132-40. 
138. Calkins H, Kuck KH, Cappato R, Brugada J, Camm AJ, Chen SA, et al. 2012 HRS/EHRA/ECAS expert consensus statement on catheter and surgical ablation of atrial fibrillation: recommendations for patient selection, procedural techniques, patient management and follow-up definitions, endpoints, and research trial design: a report of the Heart Rhythm Society (HRS) Task Force on Catheter and Surgical Ablation of Atrial Fibrillation. Developed in partnership with the European Heart Rhythm Association (EHRA), a registered branch of the European Society of Cardiology (ESC) and the European Cardiac Arrhythmia Society (ECAS); and in collaboration with the American College of Cardiology (ACC), American Heart Association (AHA), the Asia Pacific Heart Rhythm Society (APHRS), and the Society of Thoracic Surgeons (STS). Endorsed by the governing bodies of the American College of Cardiology Foundation, the American Heart Association, the European Cardiac Arrhythmia Society, the European Heart Rhythm Association, the Society of Thoracic Surgeons, the Asia Pacific Heart Rhythm Society, and the Heart Rhythm Society. Heart Rhythm. 2012;9(4):632-696 e21.

139. McEvoy RD, Antic NA, Heeley E, Luo Y, Ou Q, Zhang X, et al. CPAP for prevention of cardiovascular events in obstructive sleep apnea. N Engl J Med. 2016;375(10):919-31.

140. Esquinas C, Sanchez-de-la Torre M, Aldoma A, Flores M, Martinez M, Barcelo A, et al. Rationale and methodology of the impact of continuous positive airway pressure on patients with ACS and nonsleepy OSA: the ISAACC trial. Clin Cardiol. 2013;36(9):495-501.

141. Buchner S, Satzl A, Debl K, Hetzenecker A, Luchner A, Husser O, et al Impact of sleep-disordered breathing on myocardial salvage and infarct size in patients with acute myocardial infarction. Eur Heart J. 2014;35(3):192-9.

142. Buchner S, Eglseer M, Debl K, Hetzenecker A, Luchner A, Husser O, et al. Sleep disordered breathing and enlargement of the right heart after myocardial infarction. Eur Respir J. 2014;45(3):680-90.

143. Disler P, Hansford A, Skelton J, Wright P, Kerr J, O'Reilly J, et al. Diagnosis and treatment of obstructive sleep apnea in a stroke rehabilitation unit: a feasibility study. Am J Phys Med Rehabil. 2002;81(8):622-5.

144. Minnerup J, Wersching H, Ringelstein EB, Dziewas R, editors. Nasal continuous positive airway pressure therapy in acute stroke: results of a feasibility study (abstract 3710). International stroke conference; 2012; New Orleans.

145. Wessendorf TE, Wang YM, Thilmann AF, Sorgenfrei U, Konietzko N, Teschler H. Treatment of obstructive sleep apnoea with nasal continuous positive airway pressure in stroke. Eur Respir J. 2001;18(4):623-9.

146. Kohler M, Pepperell JC, Casadei B, Craig S, Crosthwaite N, Stradling JR, et al. CPAP and measures of cardiovascular risk in males with OSAS. Eur Respir J. 2008;32(6):1488-96.

147. GLYCOSA Study. Effect of PAP treatment on glycemic control in patients with type 2 diabetes. http://clinicaltrials.gov/ct2/show/NCT00509223?t erm $=$ nct00509223\&rank=1. Accessed 8 Nov 2013.

148. American Association of Clinical Endocrinologists. American Association of Clinical Endocrinologists Medical Guidelines for Clinical Practice for Developing a Diabetes Mellitus Comprehensive Care Plan. 2011. http://www.aace.com/files/dm-guidelines-ccp.pdf. Accessed 8 Nov 2013.

149. Shaw JE, Punjabi NM, Wilding JP, Alberti KG, Zimmet PZ, International Diabetes Federation Taskforce on E, et al. Sleep-disordered breathing and type 2 diabetes: a report from the International Diabetes Federation Taskforce on Epidemiology and Prevention. Diabetes Res Clin Pract. 2008:81(1):2-12

150. Machado MC, Vollmer WM, Togeiro SM, Bilderback AL, Oliveira MV, Leitao FS, et al. CPAP and survival in moderate-to-severe obstructive sleep apnoea syndrome and hypoxaemic COPD. Eur Respir J. 2010;35(1):132-7.

151. Stanchina ML, Welicky LM, Donat W, Lee D, Corrao W, Malhotra A. Impact of CPAP use and age on mortality in patients with combined COPD and obstructive sleep apnea: the overlap syndrome. J Clin Sleep Med. 2013;9(8):767-72.

152. Kohnlein T, Windisch W, Kohler D, Drabik A Geiseler J, Hartl S, et al. Noninvasive positive pressure ventilation for the treatment of severe stable chronic obstructive pulmonary disease: a prospective, multicentre, randomised, controlled clinical trial. Lancet Respir Med. 2014;2(9):698-705.

153. Murphy P, Arbane G, Bourke S, Calverley P, Dowson L, Duffy N, et al. Improving admission free survival with home mechanical ventilation (HMV) and home oxygen therapy (HOT) following life threatening COPD exacerbations: HOT-HMV UK trial. Eur Respir J. 2016;48(60):OA3527.

154. Kapur V, Blough DK, Sandblom RE, Hert R, de Maine JB, Sullivan $\mathrm{SD}$, et al. The medical cost of undiagnosed sleep apnea. Sleep. 1999;22(6):749-55.

155. Kryger MH, Roos L, Delaive K, Walld R, Horrocks J. Utilization of health care services in patients with severe obstructive sleep apnea. Sleep. 1996;19(9 Suppl):S111-6.

156. Ronald J, Delaive K, Roos L, Manfreda J, Bahammam A, Kryger MH. Health care utilization in the 10 years prior to diagnosis in obstructive sleep apnea syndrome patients. Sleep. 1999;22(2):225-9.

157. Smith R, Ronald J, Delaive K, Walld R, Manfreda J, Kryger MH. What are obstructive sleep apnea patients being treated for prior to this diagnosis? Chest. 2002;121(1):164-72.

158. Tarasiuk A, Greenberg-Dotan S, Brin YS, Simon T, Tal A, Reuveni H. Determinants affecting health-care utilization in obstructive sleep apnea syndrome patients. Chest. 2005:128(3):1310-4.

159. McKinsey \& Company. The price of fatigue: the surprising economic costs of unmanaged sleep apnea. http://sleep.med.harvard.edu/ what-we-do/public-policyresearch.

160. Access Economics Re-awakening Australia. The economic cost of sleep disorders in Australia 2010. http://www.deloitte.com/view/en_AU/au/ insights/browse-by-industry/life-sciences-and-healthcare/6c064e0963a 55310VgnVCM2000001b56f00aRCRD.htm.

161. Hillman DR, Murphy AS, Pezzullo L. The economic cost of sleep disorders. Sleep. 2006;29(3):299-305

162. Guest JF, Helter MT, Morga A, Stradling JR. Cost-effectiveness of using continuous positive airway pressure in the treatment of severe obstructive sleep apnoea/hypopnoea syndrome in the UK. Thorax. 2008;63(10):860-5.

163. Ayas NT, FitzGerald JM, Fleetham JA, White DP, Schulzer M, Ryan CF, et al. Cost-effectiveness of continuous positive airway pressure therapy for moderate to severe obstructive sleep apnea/hypopnea. Arch Intern Med. 2006;166(9):977-84.

164. Chilcott J, Clayton E, Chada N, Hanning CD, Kinnear W, Waterhouse JC. Nasal continuous positive airways pressure in the management of sleep apnoea. Leicester: Trent Institute for Health Services Research, Universities of Leicester, Nottingham and Sheffield; 2000.

165. Mar J, Rueda JR, Duran-Cantolla J, Schechter C, Chilcott J. The costeffectiveness of nCPAP treatment in patients with moderate-to-severe obstructive sleep apnoea. Eur Respir J. 2003;21(3):515-22.

166. McDaid C, Griffin S, Weatherly H, Duree K, van der Burgt M, van Hout S, et al. Continuous positive airway pressure devices for the treatment of obstructive sleep apnoea-hypopnoea syndrome: a systematic review and economic analysis. Health Technol Assess. 2009;13(4):iii-iv, xi-xiv, $1-119,43-274$

167. Tousignant P, Cosio MG, Levy RD, Groome PA. Quality adjusted life years added by treatment of obstructive sleep apnea. Sleep. 1994;17(1):52-60.

168. Gaspoz JM, Coxson PG, Goldman PA, Williams LW, Kuntz KM, Hunink $M G$, et al. Cost effectiveness of aspirin, clopidogrel, or both for secondary prevention of coronary heart disease. N Engl J Med. 2002;346(23):1800-6.

169. Pignone M, Earnshaw S, Tice JA, Pletcher MJ. Aspirin, statins, or both drugs for the primary prevention of coronary heart disease events in men: a cost-utility analysis. Ann Intern Med. 2006;144(5):326-36.

170. Franco OH, der Kinderen AJ, De Laet C, Peeters A, Bonneux L. Primary prevention of cardiovascular disease: cost-effectiveness comparison. Int J Technol Assess Health Care. 2007:23(1):71-9.

171. Feldman AM, de Lissovoy G, Bristow MR, Saxon LA, De Marco T, Kass DA, et al. Cost effectiveness of cardiac resynchronization therapy in the comparison of medical therapy, pacing, and defibrillation in heart failure (COMPANION) trial. J Am Coll Cardiol. 2005:46(12):2311-21.

172. McKenna C, Palmer S, Rodgers M, Chambers D, Hawkins N, Golder $\mathrm{S}$, et al. Cost-effectiveness of radiofrequency catheter ablation for the treatment of atrial fibrillation in the United Kingdom. Heart. 2009:95(7):542-9.

173. D'Ambrosio C, Bowman T, Mohsenin V. Quality of life in patients with obstructive sleep apnea: effect of nasal continuous positive airway pressure-a prospective study. Chest. 1999;115(1):123-9. 
174. Engleman HM, Martin SE, Deary IJ, Douglas NJ. Effect of continuous positive airway pressure treatment on daytime function in sleep apnoea/hypopnoea syndrome. Lancet. 1994;343(8897):572-5.

175. Craig SE, Kohler M, Nicoll D, Bratton DJ, Nunn A, Davies R, et al. Continuous positive airway pressure improves sleepiness but not calculated vascular risk in patients with minimally symptomatic obstructive sleep apnoea: the MOSAIC randomised controlled trial. Thorax. 2012;67(12):1090-6.

\section{Submit your next manuscript to BioMed Central and we will help you at every step:}

- We accept pre-submission inquiries

- Our selector tool helps you to find the most relevant journal

- We provide round the clock customer support

- Convenient online submission

- Thorough peer review

- Inclusion in PubMed and all major indexing services

- Maximum visibility for your research

Submit your manuscript at

www.biomedcentral.com/submit 